\title{
Desain Kapal Penyeberangan Sebagai Sarana Transportasi, Rekreasi, dan Edukasi di Pulau Gili Ketapang, Probolinggo, Jawa Timur
}

\author{
Ahlun Ridwan Saputera, dan Hasanudin \\ Departemen Teknik Perkapalan, Fakultas Teknologi Kelautan, Institut Teknologi Sepuluh Nopember \\ (ITS) \\ e-mail: hasanudin@na.its.ac.id
}

\begin{abstract}
Abstrak-Pulau Gili Ketapang adalah salah satu pulau yang indah di Kabupaten Probolinggo, Jawa Timur. Pulau ini memiliki potensi wisata yang menjanjikan, akan tetapi belum ditunjang dengan sarana transportasi yang memadai. Disana pantainya indah tapi fasilitas belum mendukung, seperti belum adanya kapal wisata. Selain itu pengelolaan wisatanya kurang maksimal, Karena minimnya Pendidikan bagi Sumber Daya Manusia (SDM) di pulau tersebut. Disana perlu suatu sarana bagi masyarakat Pulau Gili Ketapang untuk mendapat pendidikan lebih. Pada Studi ini, didesain sebuah kapal penyeberangan yang dapat digunakan sebagai transportasi, rekreasi dan edukasi. Nantinya, di dalam kapal akan ada perpustakaan kecil sebagai sarana penunjang pendidikan. Metode pendesainan yang digunakan untuk menyelesaikan studi ini adalah metode Point Base Desain. Kemudian mencari owner's requirement dan ukuran utama dari kapal. Setelah itu dilakukan perhitungan hambatan, pemilihan mesin induk, koreksi berat, penetuan titik berat, perhitungan freeboard, pehitungan stabilitas, dan koreksi trim kemudian mendesain rencana garis, rencana umum, safety plan, dan desain tiga dimensi (3D). Diharapkan dengan adanya studi ini bisa memberikan solusi transportasi, rekreasi, dan edukasi di Pulau Gili Ketapang. Dari desain yang telah dilakukan didapatkan kapal dengan payload 36 penumpang dan 2 motor ( 4.82 ton), serta mempunyai ukuran utama; $L w l=19.76 \mathrm{~m}, \mathrm{Lpp}=19 \mathrm{~m}, \mathrm{~B}=$ $4.2 \mathrm{~m}, \mathrm{H}=2 \mathrm{~m}, \mathrm{~T}=1.05 \mathrm{~m}$. Untuk biaya pembangunan, KMP Gili Ketapang Jaya menghabiskan dana Rp 2,403,921,423.68, dengan operational cost per tahun Rp1,442,696,907 kemudian mempunyai pendapatan per tahun senilai Rp2,022,100,000 sehingga keuntungan bersih pertahun adalah Rp 579,403,093. Dari hasil analisis ekonomis Break Event Point (BEP) akan terjadi pada tahun ke 6 .
\end{abstract}

Kata Kunci-Pulau Gili Ketapang, Kapal Penyeberangan, Rekreasi, Edukasi.

\section{PENDAHULUAN}

$\mathrm{P}$ ULAU Gili ketapang merupakan pulau yang cukup indah dan mempunyai potensi untuk menjadi tempat wisata yang bagus. Akan tetapi masih jarang orang yang belum mengetahui dan jarang di kunjungi. Tempat wisata yang ditawarkan oleh Pulau Gili Ketapang meliputi wisata alamnya. Disana Alamnya masih cukup asri. Terdapat gua yang terkenal dikalangan masyarakat Gili Ketapang yaitu Gua Kucing. Pantai di Pulau Gili Ketapang juga cukup bagus, pasir putih dan airnya yang jernih menjadi daya tarik yang menarik untuk wisatawan. Selain Gua dan Pantai terdapat potensi wisata lain yang menjanjikan, yaitu potensi wisata snorkeling dan diving karena air di sekitar Gili Ketapang masih sangat Jernih sehingga terumbu karang yag berada di dasar laut dapat terlihat. Luas wilayah Pulau Gili Ketapang adalah 61 ha,dengan jumlah penduduk 8.583 jiwa (2016). Sarana Prasarana di Pulau Gili Ketapang masih kurang. Belum ada tempat penginapan seperti hotel atau resort, hanya rumah singgah yang terbuka untuk wisatawan yang datang ataupun rumah warga[1].

Masyarakat disini sebagian besar hanya lulusan SD. Data dinas Kecamatan Sumberasih menunjukan, dari jumlah warga yaitu 8853 orang, 3.216 orang tidak sekolah, 563 orang tidak tamat SD, 3.129 orang tamat SD, 819 orang tamat SMP, 649 orang tamat SMA, 9 orang tamat Akademi atau Perguruan Tinggi [1]

Sarana Transportasi di Pulau ini masih terbatas, warga sekitar masih mengandalkan perahu tradisional untuk kebutuhan transportasi sehari-hari dan itu pun jadwal pemberangkatanya tidak pasti, dan jika ingin membawa kendaraan bermotor dengan kapal biayanya sangat mahal. Terkadang ada juga yang menggunakan kapal nelayan sebagai sarana transportasi sehari-hari. Oleh sebab itu, perlu pembutan kapal penyeberangan yang dapat dijadikan transportasi menuju pulau Gili Ketapang yang bisa memuat orang dan kendaraan bermotor. Kemudian dijadikan kapal wisata untuk keperluan wisata, dimana nantinya wisatawan bisa menikmati keindahan pulau tersebut dengan kapal yang aman dan nyaman serta dengan adanya wisata diharapkan akan membuat kesejahteraan warga disana meningkat . Selain itu juga pembuatan suatu wadah pembinaan dengan cara membuat perpustakaan kecil dalam kapal yang akan berkelililing ke Pulau Gili Ketapang dengan harapan bisa memberi manfaat untuk pendidikan yang lebih baik.

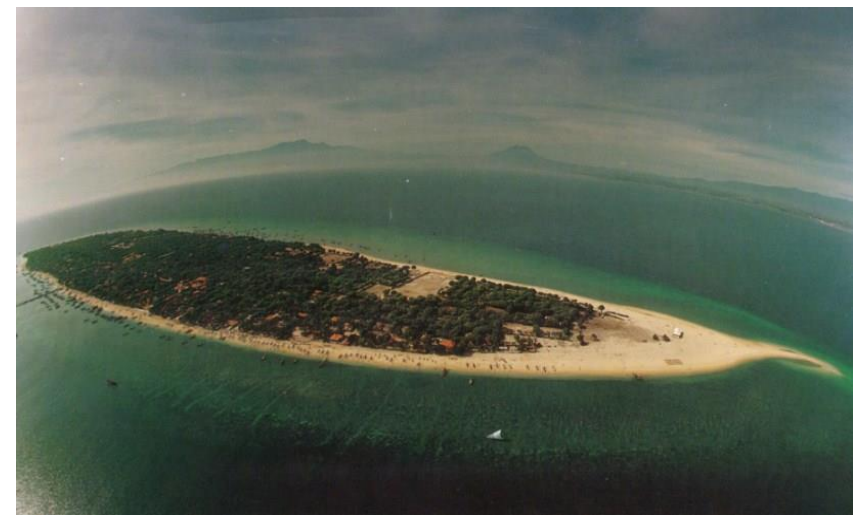

Gambar 1. Pulau Gili Ketapang tampak dari atas 


\section{TINJAUAN PUSTAKA}

\section{A. Kapal Penumpang}

Kapal penumpang (passenger boat) adalah kapal yang berfungsi untuk mengangkut penumpang tapi ada juga yang bisa mengangkut kendaraan berupa sepeda atau motor. Biasanya kapal penumpang melayani dalam rute jarak pendek (selat, sungai, dan danau). Kapal penumpang memeliki peran yang sangat vital, khususnya untuk daerah yang tidak ada penghubung jembatannya. Gambar dibawah ini merupakan kapal penumpag yang bisa membawa kendaraan.

\section{B. Wahana Rekreasi}

Dalam pendesainan kapal penyeberangan ini, fungsi utamanya memang sebagai transportasi umum. Akan tetapi kapal ini juga dapat disewa sebagai kapal wisata. Sehingga para wisatawan dapat menikmati keindahan Pulau Gili Ketapang dari kapal. Kapal ini juga menawarkan wisatawan untuk menuju tempat untuk diving dan snorkeling bagi mereka yang ingin menikmati keindahan bawah laut Pulau Gili Ketapang. Akan tetapi untuk jadwalnya berbeda dengan jadwal untuk penyeberangan. Jadwal untuk sarana rekreasi adalah pagi dan sore, dengan melihat sunrise dan sunset.

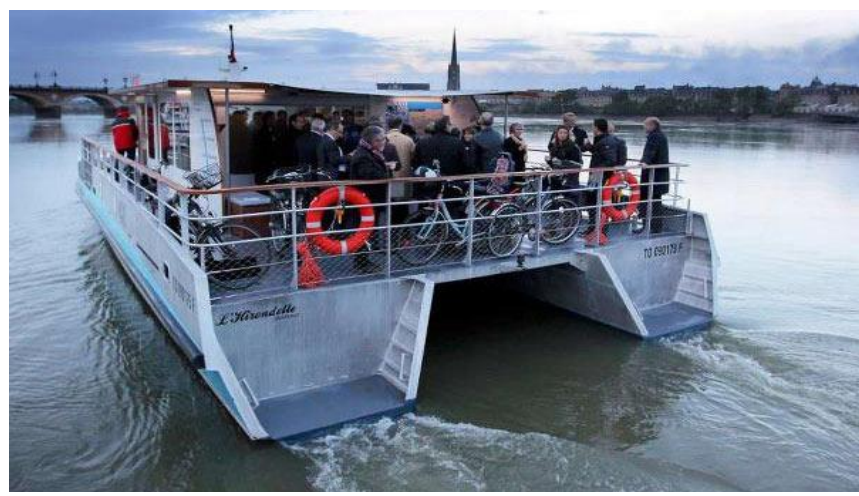

Gambar 2. Green Boat Cat DUBOURDIEU di Bordeaux (France)

\section{Perpustakaan Sebagai Sarana Edukasi}

Menurut UU perpustakaan pada Bab I pasal 1 menyatakan Perpustakaan adalah institusi yang mengumpulkan pengetahuan tercetak dan terekam, mengelolanya dengan cara khusus guna memenuhi kebutuhan intelektualitas para penggunanya melalui beragam cara interaksi pengetahuan. Perpustakaan mempunyai peran untuk memelihara dan meningkatkan efisiensi dan efektifitas proses belajarmengajar. Tujuan dari perpustakaan itu sendiri yaitu :

1. Dapat mendidik dirinya sendiri secara berkesinambungan.

2. Dapat tanggap dalam kemajuan pada berbagai lapangan ilmu pengetahuan, kehidupan sosial dan politik.

3. Dapat memelihara kemerdekaan berfikir yang konstruktif untuk menjadi anggota keluarga dan masyarakat yang lebih baik.

4. Dapat mengembangkan kemampuan berfikir kreatif, membina rohani dan dapat menggunakan kemampuannya untuk dapat menghargai hasil seni dan budaya manusia.

5. Dapat meningkatkan taraf kehidupan sehari-hari dan lapangan pekerjaannya

6. Dapat menjadi warga negara yang baik dan dapat berpartisipasi secara aktif dalam pembangunan nasional dan dalam membina saling pengertian antar bangsa.

7. Dapat menggunakan waktu senggang sengan lebih baik yang bermanfaat bagi kehidupan pribadi dan sosial [2].

\section{METEDOLOGI PENELITIAN}

\section{A. Diagram Alir}

Tahapan dari metodologi penelitian yang digunakan digambarkan pada diagram alir pada Gambar 3.

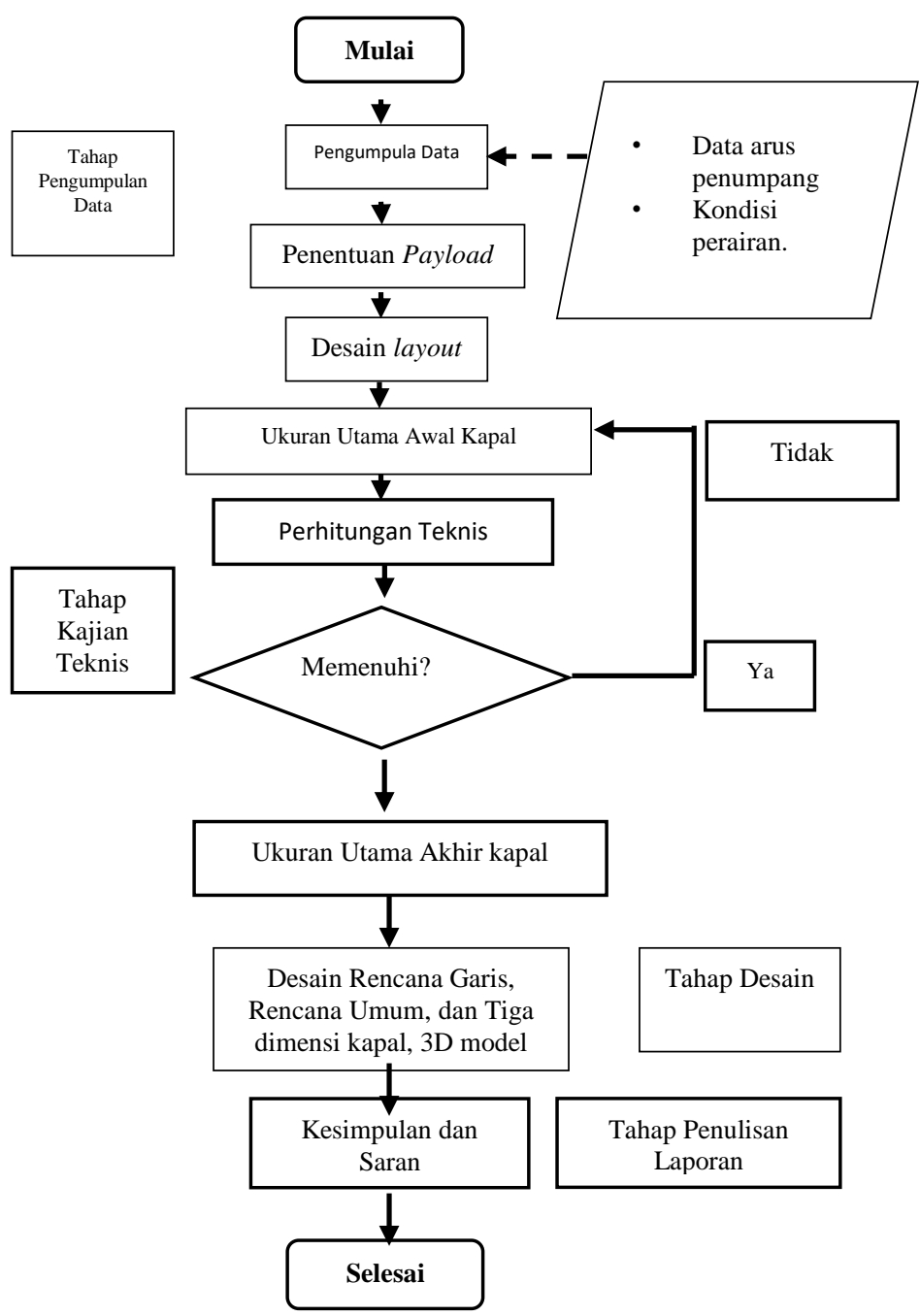

Gambar 3. Diagram alir

\section{ANALISIS TEKNIS}

\section{A. Penentuan Owner's Requirement}

Langkah awal yang dilakukan untuk mendesain kapal adalah menentukan owner's requirement.

1) Penentuan Payload

Jumlah rata-rata penumpang per trip $\quad=20$ orang

Asumsi penambahan penumpang $\quad \equiv 16$ orang +

Payload $\quad=36$ orang $+2 \mathrm{mtr}$

Asumsi Berat per orang + barang bawaan $=1.05$ ton

Berat 2 motor $\quad=0.5$ ton

Berat Payload $\quad=4.28$ ton

\section{2) Perencanaan Trip}

- Trip untuk transportasi

Jumlah rata-rata penumpang penduduk sekitar $\quad=320$ org 
Jumlah rata-rata wisatawan perhari Jumlah penumpang keseluruhan per hari Jumlah trip

- Trip untuk rekreasi direncanakan 1 kali.

- Trip untuk edukasi direncanakan 1 kali.

3) Menentukan Rute Pelayaran, Jarak Pelayaran, dan Kecepatan Kapal.

Untuk transportasi, rute pelayaran kapal pada studi ini adalah dari Pelabuhan Tanjung Tembaga menuju Pulau Gili ketapang dan sebaliknya. Jarak rute transportasi adalah 5.43 $\mathrm{km}$ untuk satu kali trip. Sedangkan untuk rekreasi dan wisata, rute pelayaran kapal ini adalah dari Pelabuhan Tanjung Tembaga menuju Pulau Gili ketapang kemudian mengelilingi Pulau Gili Ketapang dan kembali lagi ke Pelabuhan Tanjung Tembaga. Jarak rute rekreasi dan edukasi untuk satu kali trip adalah $15.85 \mathrm{~km}$. Kapal ini direncanakan memiliki kecepatan dinas 8 knot.

Setelah semua sudah direncanakan, maka didapatlah owner's requirement sebagai berikut:

- Owner's Requirements

Jenis Kapal = Kapal Motor Peyeberangan

Payload $=36$ penumpang dan 2 motor $(4.82$ ton)

Rute Pelayaran = Probolinggo-Gili Ketapang Gili Ketapang-Probolinggo

Jarak Pelayaran $\quad=15.85 \mathrm{~km}$

Kecepatan Dinas $=8$ knot

B. Desain Layout untuk Menentukan Ukuran Utama Awal Kapal

Desain layout awal ini bertujuan untuk menentukan ukuran utama awal kapal. Desain dari layout ini didasarkan pada kebutuhan payload kapal, yaitu dari penumpangnya. Selain itu juga ada batasannya yang mengacu pada kondisi perairan dan kondisi teknis lainnya.
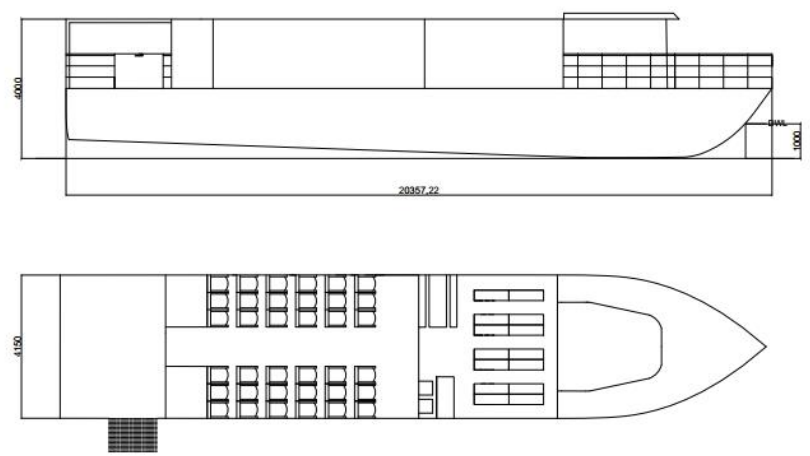

Gambar 4. Layout awal KMP Gili Ketapang Jaya

\section{Perhitungan Teknis}

\section{1) Perhitungan Koefisien}

- Ukuran Utama Awal Kapal

Ukuran utama didapat berdasarkan jumlah dan peletakan payload dari desain layout awal kapal, sehingga didapatkan ukuran utama awal sebagai berikut :

$\begin{array}{rll}\mathrm{L}_{P P} & =19 & \mathrm{~m} \\ \mathrm{~B} & =4.2 & \mathrm{~m} \\ \mathrm{H} & =2 & \mathrm{~m} \\ \mathrm{~T} & =1.05 & \mathrm{~m}\end{array}$

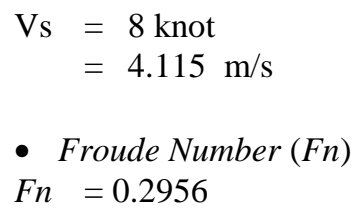

- Perhitungan rasio ukuran utama

$\mathrm{L} / \mathrm{B}=4.524$; PNA Vol. I hal. $19 \rightarrow 3<\mathrm{L} / \mathrm{B}<10$

$\mathrm{B} / \mathrm{T}=4.000 ;$ PNA Vol. I hal. $19 \rightarrow 1.8<\mathrm{B} / \mathrm{T}<5$

$\mathrm{L} / \mathrm{T}=18.095$; PNA Vol. I hal. $19 \rightarrow 10<\mathrm{L} / \mathrm{T}<30[3]$

$\mathrm{L} / 16=1.188 ;$ BKI Vol. II Tahun $2014 \rightarrow \mathrm{H}>\mathrm{L} / 16$

$\mathrm{C}_{\mathrm{B}}=0,540$

$\mathrm{C}_{\mathrm{M}}=0,972$

$\mathrm{C}_{\mathrm{WP}}=0,658$

$\mathrm{V}=47.086 \mathrm{~m}^{3}$

$\mathrm{D}=48.263$ ton

\section{2) Perhitungan Hambatan}

Metode yang digunakan untuk menghitung tahanan kapal menggunakan Metode Holtrop [3] dan menggunakan softwere Maxsurf Educational Version. Untuk perhitungannya adalah sebagai berikut:

Dari softwere Maxsurf Educational Version diperoleh nilai hambatan total 5,284 kN, Margin 15\%, sehingga RT = $6.077 \mathrm{kN}$.

3) Perhitungan Propulsi dan Daya Mesin Induk

Dari perhitungan didapatkan BHP sebesar $55.369 \mathrm{~kW}$ atau 75.280 HP. Kapal ini akan menggunakan mesin merk John Deere dengan daya $60 \mathrm{~kW}, 80 \mathrm{HP}$.

4) Perhitungan Berat, Koreksi Displacement, dan Titik Berat

Berat dan titik berat merupakan komponen penting dalam mendesain kapal, yang berpengaruh langsung pada stabilitas kapal, performance, dan biaya. Berat kapal terdiri dari Dead Weight Tonnes (DWT) dan Light Weight Tonnes (LWT)[4]. Total berat kapal ini adalah 43.549 ton. Agar koreksi displacement terpenuhi, selisih berat kapal dan displacement kapal harus ada pada range 1-10\%. Selisih perhitungan berat kapal dengan berat displacement kapal pada studi ini adalah 4.714 ton, bila dijadikan persen hasilnya adalah $9.767 \%$. Jadi koreksi displacement kapal ini terpenuhi dan dapat diterima. Pada perhitungan titik berat, nilai keel to gravity (KG) untuk kapal ini sebesar $1.938 \mathrm{~m}$ dan nilai longitudinal centre of gravity (LCG) sebesar $9.439 \mathrm{~m}$ dari AP.

5) Perhitungan Freeboard

Lambung timbul atau freeboard pada kapal ini akan dihitung menggunakan peraturan Non Conventional Vessel Standard (NCVS), dimana dari hasil perhitungan didapatkan batasan minimal $0.152 \mathrm{~m}$, actual freeboard di desain dengan tinggi $0.950 \mathrm{~m}$. Actual freeboard harus lebih besar dari freeboard perhitungan, Karena actual freeboard lebih besar nilainya dari freeboard perhitungan, maka kriteria freeboard memenuhi.

\section{6) Perhitungan Stabilitas}

Kapal yang akan dibangun harus dapat dibuktikan secara teoritis bahwa kapal tersebut memenuhi standard keselamatan pelayaran Safety Of Life At Sea (SOLAS) atau International Maritime Organization (IMO). Perhitungan stabilitas dilakukan dengan bantuan software Maxsurf Educational Version. Kriteria stabilitas yang digunakan dalam perhitungan software adalah IS Code 2008[6] dengan kriteria loadcase pada studi ini sebagai berikut:

a. Loadcase I : muatan $100 \%$ dan consummable $100 \%$ 
b. Loadcase II : muatan $100 \%$ dan consummable $50 \%$

c. Loadcase III : muatan $100 \%$ dan consummable $10 \%$

d. Loadcase IV : muatan $70 \%$ dan consummable $100 \%$

e. Loadcase V : muatan $70 \%$ dan consummable $50 \%$

f. Loadcase VI : muatan $70 \%$ dan consummable $10 \%$

Pada table 1 Dibawah ini merupakan rekapitulasi hasil analisis stabilitas dalam berbagai kondisi yang telah dibandingkan dengan kriteria batasanya:

Tabel 1.

Rekapitulasi Perhitungan Stabilitas Pada Setiap Loadcase

\begin{tabular}{|c|c|c|c|c|c|c|}
\hline $\begin{array}{c}\text { Data/ } \\
\text { Kriteria }\end{array}$ & $\begin{array}{l}\text { Loadcase } \\
\text { I }\end{array}$ & $\begin{array}{c}\text { Loadcas } \\
\text { e } \\
\text { II }\end{array}$ & $\begin{array}{c}\text { Loadcas } \\
\text { e } \\
\text { III }\end{array}$ & $\begin{array}{c}\text { Loadcas } \\
\text { e IV }\end{array}$ & $\begin{array}{l}\text { Loadca } \\
\text { se } \\
\text { V }\end{array}$ & $\begin{array}{c}\text { Loadca } \\
\text { se VI }\end{array}$ \\
\hline $\begin{array}{l}\mathrm{e}_{0-30^{\circ} / \geq} \\
3.1513^{\circ}\end{array}$ & $6.4227^{\circ}$ & 6.0059 & $\begin{array}{c}5.0312 \\
0\end{array}$ & $\begin{array}{c}6.6726 \\
0\end{array}$ & $\begin{array}{c}6.0736 \\
\mathrm{o}\end{array}$ & $5.015^{\circ}$ \\
\hline $\begin{array}{c}\mathrm{e} 0-40^{\circ} \geq \\
5.1566 \\
o\end{array}$ & $9.3569^{\circ}$ & 8.5505 & $\begin{array}{c}6.9558 \\
o\end{array}$ & $\begin{array}{c}9.6329 \\
\text { o }\end{array}$ & $\begin{array}{c}8.7142 \\
\text { o }\end{array}$ & $\begin{array}{c}6.9847 \\
o\end{array}$ \\
\hline $\begin{array}{c}\mathrm{e}_{30-40 \%} \geq \\
1.7189 \\
\circ\end{array}$ & $2.8142^{\circ}$ & 2.5445 & $\begin{array}{c}1.9245 \\
\mathrm{o}\end{array}$ & $\begin{array}{c}2.9603 \\
\text { o }\end{array}$ & $\begin{array}{c}2.6405 \\
o\end{array}$ & $\begin{array}{c}1.9697 \\
\text { o }\end{array}$ \\
\hline $\begin{array}{c}\mathrm{h}_{30^{\circ} \%} \geq \\
0.2^{\circ}\end{array}$ & $0.313^{\circ}$ & 0.281 & $0.223^{\circ}$ & $0.324^{\circ}$ & $0.287^{\circ}$ & $0.226^{\circ}$ \\
\hline $\begin{array}{c}\theta_{\max /} \\
\geq 25^{\circ}\end{array}$ & $28.6^{\circ}$ & 28.2 & $25.5^{\circ}$ & $29.1^{\circ}$ & $28.6^{\circ}$ & $25.9^{\circ}$ \\
\hline $\begin{array}{c}\mathrm{GM}_{0 /} \geq \\
0.15^{\circ}\end{array}$ & $1.017^{\circ}$ & $1.006^{\circ}$ & $0.908^{\circ}$ & $1.054^{\circ}$ & $1.031^{\circ}$ & $0.918^{\circ}$ \\
\hline Kondisi & Diterima & Diterima & Diterima & Diterima & Diterima & $\begin{array}{c}\text { Diterim } \\
\mathbf{a}\end{array}$ \\
\hline
\end{tabular}

\section{7) Perhitungan Batasan Trim}

Trim dapat didefinikan sebagai perbedaan sarat belakang dan sarat depan. Trim terjadi sebagai akibat dari tidak meratanya momen statis dari penyebaran gaya berat. Trim dibedakan menjadi dua, yaitu trim haluan dan trim buritan [5]. Menurut Non Conventional Vessel Standard (NVCS) Indonesian Flagged, batasan trim yang diizinkan tidak boleh melebihi dari LBP/50. Kondisi trim didapatkan secara otomatis saat perhitungan stabilitas di Maxsurf Educational Version. Jika hasilnya positif, berarti trim buritan, jika negatif, berarti trim haluan. Pada Tabel 2. merupakan hasil rekapitulasi pemeriksaan batasan trim.

Tabel 2.

Rekapitulasi Kondisi Trim Pada Setiap Loadcase

\begin{tabular}{ccccc}
\hline \hline No & Kondisi & Batasan & Nilai & Status \\
\hline 1 & Loadcase 1 & $-0,38 \leq$ trim $\leq 0.38$ & 0.234 & Diterima \\
2 & Loadcase 2 & $-0,38 \leq$ trim $\leq 0.38$ & 0.041 & Diterima \\
3 & Loadcase 3 & $-0,38 \leq$ trim $\leq 0.38$ & -0.125 & Diterima \\
4 & Loadcase 4 & $-0,38 \leq$ trim $\leq 0.38$ & 0.192 & Diterima \\
5 & Loadcase 5 & $-0,38 \leq$ trim $\leq 0.38$ & -0.004 & Diterima \\
6 & Loadcase 6 & $-0,38 \leq$ trim $\leq 0.38$ & -0.175 & Diterima \\
\hline \hline
\end{tabular}

Kondisi trim kapal pada semua loadcase telah memenuhi.

\section{8) Pembuatan Rencana Garis atau Lines Plan}

Recana garis atau lines plan merupakan gambar yang menyatakan bentuk potongan badan kapal yang memiliki tiga sudut pandang yaitu, body plan (secara melintang), sheer plan (secara memanjang) dan half breadth plan (dilihat dari atas). Dalam pembuatan desain rencana garis, KMP Gili Ketapang Jaya mnggunakan Software Maxsurf Educational Version dan menggunakan bantuan sample design yang sudah ada. Kapal ini dibuat dngan 21 station dengan jarak 0.95 m, 6 waterlines (WL), dengan jarak antar
WL sebesar $0.40 \mathrm{~m}$, untuk buttocks lines (BL) dibuat sebanyak 8 garis dengan jarak antar BL sebesar $0.60 \mathrm{~m}$.

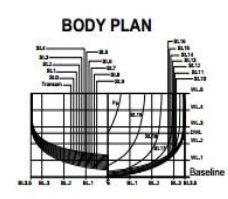

SHEER PLAN
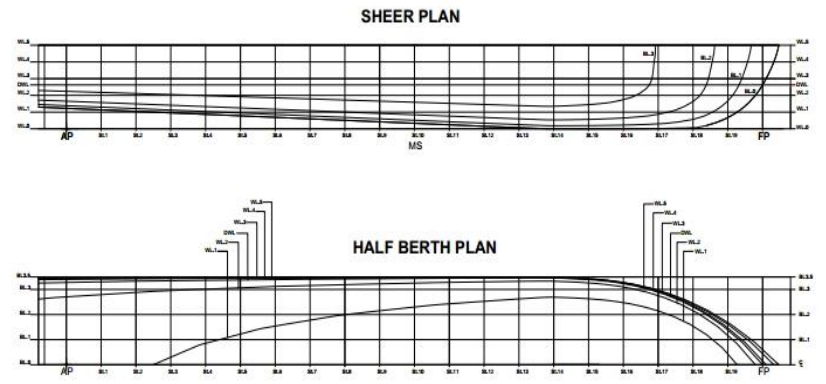

Gambar 5. Lines plan KMP Gili Ketapang Jaya

9) Pembuatan Rencana Umum atau General Arrangement

General Arrangement didefinisikan sebagai perencanaan ruangan yang dibutuhkan sesuai dengan fungsi dan perlengkapannya. Ruangan-ruangan tersebut misalnya: ruang muat, ruang akomodasi, ruang mesin, dan lain-lain. Rencana Umum dibuat berdasarkan rencana garis yang telah dibuat sebelumnya. Pada rencana umum ini jarak gading kapal adalah 0,6 m. pada main deck/geladak utama terdapat ruang penumpang, motor, perpustakaan, ruang navigasi, dan toilet. Bagian yang terakhir adalah below main deck, di sini terdapat store dan tanki-tangki. Gambar selengkapnya bisa dilihat pada gambar 6 .

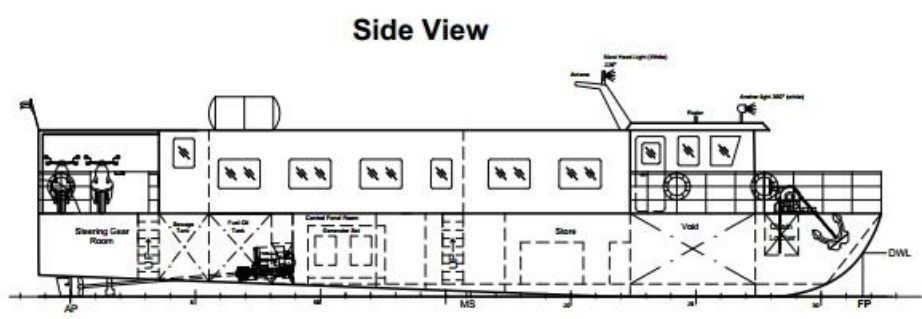

Main Deck

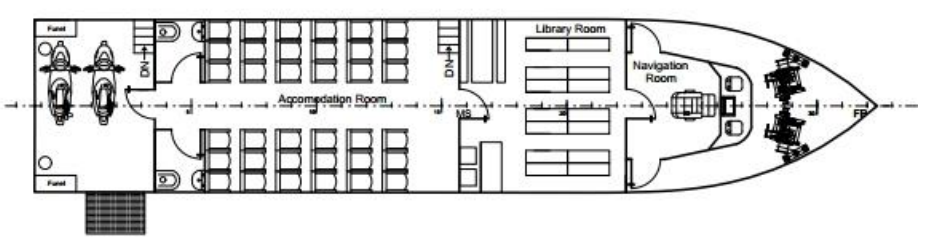

Below Main Deck

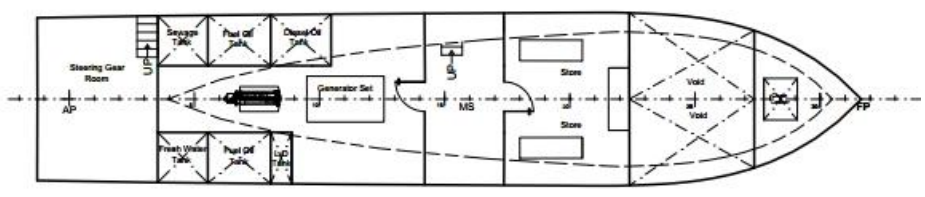

Gambar 6. General Arrangement KMP Gili Ketapang Jaya

10) Pembuatan Safety Plan

Peralatan keselamatan wajib ada dalam suatu kapal. Terlebih lagi pada kapal yang memuat banyak penumpang. Peralatan keselamatan yang digunakan pada kapal ini antar lain adalah lifeboy, life jacket, life raft, muster/assembly 
stasion, escape routes, visual signal, radio, navigation, fire control equipment, dan lampu navigasi. Perencanaan safety plan bisa dilihat pada gamabar 7 [6].
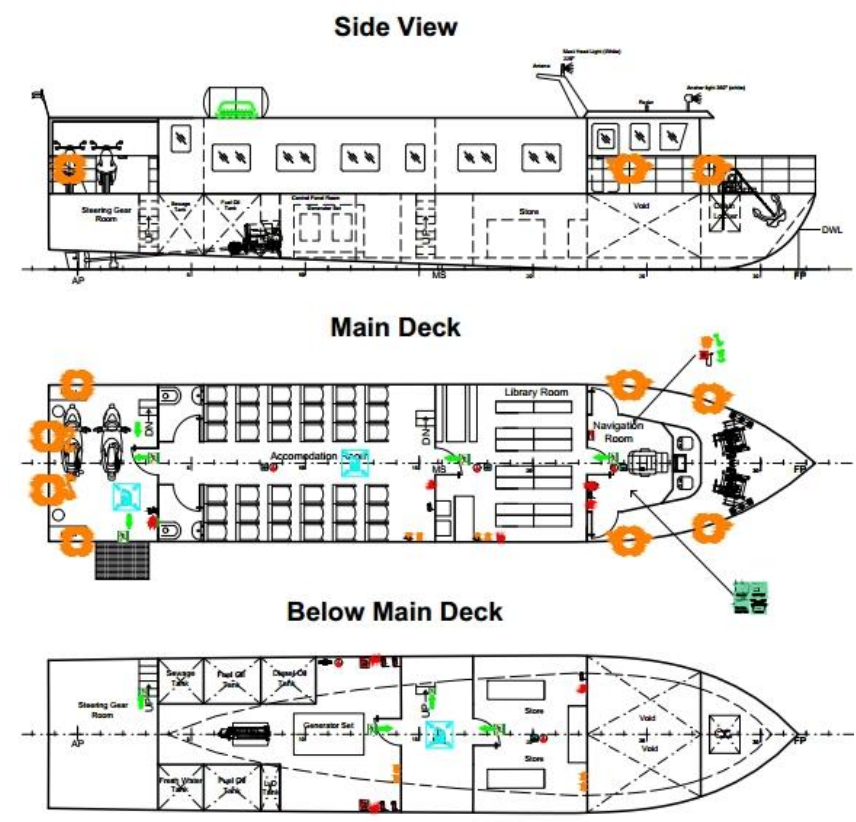

Gambar 7. Safety plan KMP Gili Ketapang Jaya

11) Pembuatan Desaian Tiga Dimensi (3D)

Pembuatan model kapal ini harus sesuai dengan ukuran utama kapal. Agar nantinya bisa menggambarkan kapal saat sudah selesai dibangun. Gambar 3D kapal ini bisa dilihat pada gambar 8 .

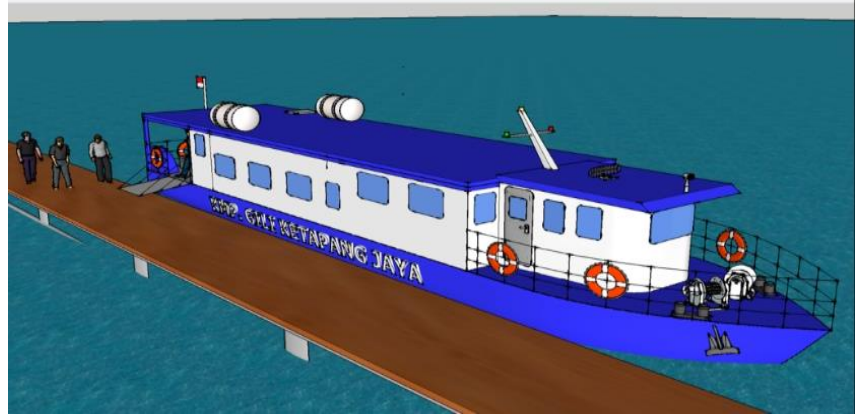

Gambar 8. Tampilan 3D KMP Gili Ketapang Jaya tampak samping

Pada gambar IV.5. terlihat ada peralatan safety seperti life raft yang terletak diatas kapal, kemudian ada lifeboy yang terletak di railling kapal. Pada bagian depan terlihat ada jangkar dan winch serta terdapat antena, radar, dan lampu navigasi.

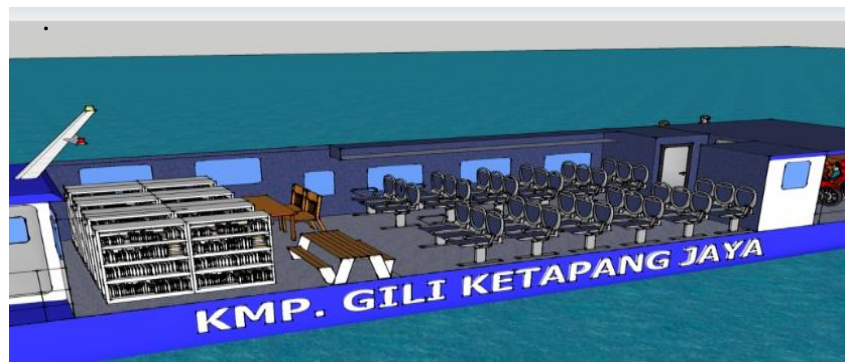

Gambar 9. Desain 3D bagian interior KMP Gili Ketapang Jaya

Interior kapal ini bisa dilihat pada gambar 9. dimana terdapat ruang akomodasi, ruang perpustakaan yang nantinya menjadi tempat membaca bagi warga di Pulau Gili Ketapang untuk menambah ilmu pengetahuan, dan terdapat dua toilet.

\section{ANALISIS EKONOMIS}

\section{A. Perhitungan Estimasi Biaya Pembangunan Kapal}

Dalam membangun kapal ini banyak komponen yang diperhitungkan yaitu biaya pelat alumunium, biaya perlengkapan, biaya motor penggerak, serta biaya kelistrikan. Total biaya pembangunan kapal ini adalah Rp. 2,403,921,423.68.

\section{B. Perhitungan BEP}

\section{1) Biaya Operasional}

Biaya operasional merupakan biaya yang harus dikeluarkan owner kapal secara rutin selama kapal beroperasi. Pada studi ini, biaya operasional akan dihitung per tahun. Beberapa faktor yang mempengaruhi besarnya biaya operasional di antaranya biaya perawatan kapal, asuransi, gaji kru/komplemen kapal, cicilan pinjaman bank, air bersih, dan biaya bahan bakar. Total biaya operasional yang harus dikeluarkan dalam satu tahun untuk kapal ini adalah Rp. 1,442,696,907.

\section{2) Perencanaan Trip}

KMP Gili Ketapang Jaya adalah kapal yang akan berfungsi sebagia sarana transportasi penyeberangan, rekreasi dan edukasi. Pada trip penyeberangan kapal ini akan melakukan 10 kali trip, untuk keperluan wisata atau rekreasi kapal ini akan melakukan satu kali trip, dan untuk edukasi akan melakukan satu kali trip setiap harinya. Pemasukan didapat dari trip penyeberangan dan wisata, sedangkan edukasi tidak ada.

\section{3) Perencanaan Harga Tiket dan Pendapatan}

Perencanaan harga tiket untuk penumpang adalah sebesar Rp. 5,000 untuk motor adalah Rp. 7,000 kemudian untuk wisata adalah Rp. 100,000. Total pendapatan per harinya adalah Rp. 3,794,000 jika dihitung per tahun, pendapatanya menjadi Rp. 2,022,100,000.

4) Estimasi Keuntungan Bersih

Keuntungan bersih pada studi ini dihitung dalam satu tahun. Keuntungan bersih didapat dari pendapatan kapal selama satu tahun - biaya operasional kapal selama satu tahun. Dari hasil tersebut KMP Gili Ketapang Jaya direncanakan mendapat keuntungan bersih sebanyak $\mathrm{Rp}$ $579,403,093$ per tahun.

5) Perhitungan $B E P$

Perhitungan BEP dalam pembangunan kapal ini dapat dilihat pada tabel 3 . 
Tabel 3.

Perhitungan BEP

\begin{tabular}{ccccc}
\hline \hline \multicolumn{5}{c}{ Perhitungan BEP } \\
\hline \multirow{2}{*}{ Tahun } & Cash Flow & Comulative \\
& Cash Inflow & Cash Outflow & Net Cashflow \\
\hline & - & & & $-2,403,921,423$ \\
& $2,403,921,423$ & & & $-1,824,518,331$ \\
2 & $2,022,100,000$ & $-1,442,696,907$ & $579,403,093$ & $-1,245,115,238$ \\
3 & $2,022,100,000$ & $-1,442,696,907$ & $579,403,093$ & $-665,712,145$ \\
4 & $2,022,100,000$ & $-1,442,696,907$ & $579,403,093$ & $-86,309,052$ \\
5 & $2,022,100,000$. & $-1,442,696,907$ & $579,403,093$ & $493,094,041$ \\
6 & $2,022,100,000$ & $-1,442,696,907$ & $579,403,093$ & $4,072,497,134$ \\
7 & $2,022,100,000$ & $-1,442,696,907$ & $579,403,093$ & 1,07 \\
\hline \hline
\end{tabular}

Dari tabel 3. dapat disimpulkan bahwa BEP akan terjadi pada tahun ke 6 .

\section{KESIMPULAN DAN SARAN}

Setelah proses desain terselesaikan maka didapat kesimpulan dan saran sebagai berikut :

1. Didapatkan owner's requirement sebagai berikut:
Jenis Kapal
$=$ Kapal Motor Peyeberangan
Payload $=36$ penumpang dan 2 motor (4.82 ton)
Rute Pelayaran = Proboliggo-Gili Ketapang
Jarak Pelayaran $=15.85 \mathrm{~km}$
Gili Ketapang-Probolinggo
Kecepatan Dinas $=8 \mathrm{knot}$

2. Didapatkan ukuran utama akhir kapal yaitu:

$$
\begin{aligned}
\text { Lwl } & =19.76 \mathrm{~m} \\
\mathrm{Lpp} & =19 \mathrm{~m} \\
\mathrm{~B} & =4.2 \mathrm{~m} \\
\mathrm{H} & =2 \mathrm{~m} \\
\mathrm{~T} & =1.05 \mathrm{~m}
\end{aligned}
$$

3. a). Dihasilkan Lines Plan

b). Dihasilkan General Arrangement

c). Dihasilkan Safety Plan d). Dihasilkan gambar tiga dimensi (3D)

4. Berdasarkan Analisis Ekonomis yang dilakukan, didapatkan biaya investasi pembangunan KMP Gili Ketapang Jaya sebesar Rp 2,403,921,424. Estimasi keuntungan bersih pertahun dari kapal ini adalah sebesar Rp 579,403,093 dan didapatkan BEP pada tahun ke-6.

Saran berisi tentang hal-hal yang dapat dikembangkan dari Studi ini, yang nantinya dapat dijadikan judul oleh Studi selanjutnya, serta kekurangan-kekuarangan yang terdapat dalam Studi ini, yaitu:

1. Dengan banyaknya estimasi dan pendekatan dalam pengerjaan Studi ini maka dapat dilanjutkan dengan pengerjaan lebih lanjut secara spesifik dalam konteks analisis ekonomis.

2. Perhitungan Kekuatan Memanjang masih belum dikaji, sehingga perlu dilakukan kajian tentang perhitungan kekuatan memanjang dari kapal ini.

\section{DAFTAR PUSTAKA}

[1] B. P. S. (BPS) K. Probolinggo, "Badan Pusat Statistik (BPS) Kabupaten Probolinggo," Badan Pusat Statistik (BPS) Kabupaten Probolinggo website, 2017. [Online]. Available: https://probolinggokab.bps.go.id/website/pdf_publikasi/StatistikDaerah-Kecamatan-Sumberasih-Tahun-2016.pdf.

[2] R. Aryadiandra, "Desain Kapal Penyeberangan Sebagai Sarana Transportasi, Rekreasi, Dan Edukasi Di Pulau Giliyang," J. Tek. POMITS, 2015.

[3] J. H. and G. G. Mennen, An approximate power prediction method. 1982

[4] Hasanudin, "Desain Kapal LCU TNI-AL Menggunakan Metode Optimisasi," J. Tek. POMITS, 2015.

[5] K. Khotimah, "Desain Kapal untuk Wisata Rute Bangsring-Pulau Menjangan-Pulau Tabuhan," J. Tek. POMITS, 2016.

[6] F. Rohmadhana, "Analisis Teknis dan Ekonomis Konversi Landing Craft Tank (LCT) Menjadi Kapal Motor Penyeberangan (KMP) Tipe Ro-ro untuk Rute Ketapang (Kabupaten Banyuwangi) - Gilimanuk (Kabupaten Jembrana)," Publ. Ilm Online Mhs. ITS, vol. 5, no. 2, 2016. 